\title{
Reappraisal of the Systematic Position of the Supposed Pinnotherid Crab Pseudopinnixa carinata (Crustacea: Decapoda: Brachyura)
}

\author{
Tomoyuki Komai ${ }^{1}$ and Kooichi Konishi ${ }^{2}$ \\ ${ }^{1}$ Natural History Museum and Institute, Chiba, 955-2 Aoba-cho, Chuo-ku, Chiba 260-8682, Japan \\ E-mail:komai@chiba-muse.or.jp \\ ${ }^{2}$ National Research Institute of Fisheries Science, Fisheries Research Agency, \\ 2-12-4 Fukuura, Yokohama, Kanagawa 236-8648, Japan \\ E-mail:kzoea@affrc.go.jp
}

(Received 24 April 2011; Accepted 31 July 2011)

\begin{abstract}
The systematic position of the monotypic eubrachyuran genus Pseudopinnixa Ortmann, 1894, which traditionally has been placed in the family Pinnotheridae, is reassessed on the basis of the adult morphology. The structure of the thoracic sternum, third maxilliped, and male abdomen strongly suggests a close relationship between Pseudopinnixa and members of the subfamily Gaeticinae in the family Varunidae. Consequently, the genus is transferred to this varunid subfamily. This assignment is also supported by the first zoeal morphology. The type species, $P$. carinata Ortmann, 1894 , is redescribed and illustrated in detail.
\end{abstract}

Key Words: Crustacea, Decapoda, Brachyura, Varunidae, Pseudopinnixa, redescription.

\section{Introduction}

Recent studies have rearranged or questioned the classification of the taxa traditionally placed in the eubrachyuran family Pinnotheridae ( $\mathrm{Ng}$ et al. 2008; Ahyong and $\mathrm{Ng}$ 2009; Naruse and Clark 2009; Palacios-Theil et al. 2009). The monotypic genus Pseudopinnixa was originally established by Ortmann (1894) in his new family Pinnotheridae, to accommodate P. carinata Ortmann, 1894 (Ortmann 1894: 690). Since then, this genus has remained in this family (e.g., Tesch 1918; Schmitt et al. 1973; Sakai 1965, 1976; Ng et al. 2008); however, based on DNA sequences and larval morphology, Cuesta et al. (2005) suggested that $P$. carinata is actually allied to the Macrophthalmidae Dana, 1851 instead. Ng et al. (2008) pointed out that a reappraisal of the systematic position of this taxon is necessary. Palacios-Theil et al. (2009), using molecular datasets, investigated the phylogenetic relationships among selected taxa of Pinnotheridae and their results indicate that the family is polyphyletic. Pseudopinnixa carinata, in particular, was positioned basally to all other pinnotheroid groups, but in a poorly resolved polytomy.

This study focuses mainly on the adult morphology of Pseudopinnixa carinata in order to assess its phylogenetic position. Our morphological studies strongly suggest that Pseudopinnixa is closely allied to the subfamily Gaeticinae Davie and Ng, 2007 in the family Varunidae Milne Edwards, 1853 , currently represented by three genera, Gaetice Gistel, 1848, Gopkittisak Naruse and Clark, 2009, and Sestrostoma Davie and Ng, 2007 (Davie and Ng 2007; Naruse and Clark 2009). This relationship is supported by the structure of the third maxilliped, thoracic sternum, and male abdomen. Consequently we propose to transfer Pseudopinnixa carinata to the Gaeticinae in the Varunidae.

\section{Materials and Methods}

Material examined in this study is deposited in the Natural History Museum and Institute, Chiba (CBM) and the Musée Zoologique, Strasbourg (ZMS). The measurements provided, in millimeters, are of the carapace length and width, respectively. For comparison, the following material was examined.

Gaetice depressus (De Haan, 1833): 1 male $(13.0 \times 16.0 \mathrm{~mm})$, Uchinoura Bay, Usa, Kochi Prefecture, intertidal, 12 September 1999, coll. H. Endo, CBM-ZC 5222.

Gopkittisak gallardoi (Serène and Soh, 1976): 2 females, Ko Sirei, Phuket, Thailand, intertidal sand flat, 22 December 2009, yabbie pump, coll. T. Komai, CBM-ZC 10225.

Sestrostoma balssi (Shen, 1932): 1 male $(9.2 \times 11.3 \mathrm{~mm})$, 1 female $(9.9 \times 12.7 \mathrm{~mm})$, Miho Bay, Tottori Prefecture, $35^{\circ} 28.903^{\prime} \mathrm{N}, 133^{\circ} 18.576^{\prime} \mathrm{E}, 12 \mathrm{~m}$, sand, 18 August 2003, Smith-McIntyre grab, CBM-ZC 8146.

\section{Systematics}

Superfamily Grapsoidea MacLeay, 1838 Family Varunidae Milne Edwards, 1853 Subfamily Gaeticinae Davie and Ng, 2007 Genus Pseudopinnixa Ortmann, 1894 
Pseudopinnixa Ortmann, 1894: 694; Schmitt et al. 1973: 126; Sakai 1976: 586.

Type-species. Pseudopinnixa carinata Ortmann, 1894, by monotypy (see Remarks).

Diagnosis. Carapace subtrapezoidal in general shape with rounded margins, wider than long; dorsal surface smooth, regions not demarcated, trace of cervical groove discernible; frontal margin slightly produced medially; no teeth on anterolateral margin; posterolateral margin weakly delimited. Orbit small; eye completely filling orbit, movable; lower orbital margin clearly separated from suborbital ridge, unarmed. Epistome broad, medially concave, posterior margin pointed medially. First to third thoracic sternites of male clearly separated by transverse sutures; anterior margin of first sternite broad, trilobed; anterolateral angles of second sternite produced anteriorly. Third maxillipeds completely filling buccal cavern, no gape when closed; articulation between ischium and merus distinct, transverse; dactylus distinctly longer than propodus, spatulate, bearing prominent tuft of setae on magins and inner face, setae reaching concavity of first to third thoracic sternites; exopod with mesial half covered by lateral margin of ischium-merus of endopod, flagellum short. Chelipeds equal or subequal, fingers subequal in length to palm; no tuft or patch of setae at base of gape between fingers. Anterior part of male thoracic sternum with shallow median concavity to accommodate elongate setae on dactylus of third maxilliped. Male abdomen moderately narrowly triangular, third to sixth somites functionally fused but with suture lines distinct on outer surface. First gonopod compressed laterally, cross-section subovate. Second gonopod much shorter than first gonopod.

Distribution. Known only from Japan.

Remarks. Ortmann (1894) did not designate a type species for his new genus Pseudopinnixa, but Pseudopinnixa carinata should be regarded as the type species by monotypy (see Ng et al. 2008). Holmes (1894: 565) proposed a new genus, Pseudopinnixa, for a pinnotherid species Pinnixa nitida Lockington, 1876 known from the eastern Pacific, but Holmes himself realized that the name Pseudopinnixa had been already used by Ortmann (1894) (Holmes 1894: 587). In this same paper, Holmes (1984: 587) proposed a replacement name Parapinnixa Holmes, 1894 for his Pseudopinnixa.

As mentioned before, the systematic position of Pseudopinnixa carinata has recently been the subject of discussion. Cuesta et al. (2005) first suggested a close relationship of this taxon to members of Grapsoidea and Ocypodoidea, especially the Macrophthalmidae. Palacios-Theil et al. (2009) commented that Pseudopinnixa might warrant eventual treatment as a separate family of the Pinnotheroidea. Our examination, however, has revealed that $P$. carinata has the diagnostic characters of the Gaeticinae (see Davie and $\mathrm{Ng}$ 2007): (1) the distal three segments of the third maxilliped are elongate, with the dactylus possessing long, brush-like setae probably associated with suspension feeding; (2) the anterior part of the thoracic sternum has a shallow median concavity, in which setae on the dactylus of the third maxil- liped are accommodated; and (3) the third to sixth abdominal somites of the male are functionally fused although the sutures are clearly defined on the outer surface. In addition, the following characters are shared with Sestrostoma: (1) the carapace is devoid of anterolateral teeth; (2) the orbit is small, filled by the eye; and (3) the anterolateral angles of the second thoracic sternite are produced anteriorly. As a result of these observations, we propose to transfer P. carinata, to the Gaeticinae.

Pseudopinnixa is unique within the Gaeticinae in having the following features: (1) the carapace is roundly subtrapezoidal; (2) there is no inner orbital tooth on the lower orbital margin; (3) the male first thoracic sternite is trilobed anteriorly; (4) the mesial half of the exopod of the third maxilliped is covered by the lateral margin of the ischiummerus of the endopod; and (5) the first gonopod is laterally compressed, its cross-section being subovate. The carapace is more distinctly trapezoidal with posteriorly converging lateral margins in Gaetice, and nearly elliptical in Gopkittisak and Sestrostoma. The lower orbital margin has a distinct inner orbital tooth and the male first thoracic sternite is triangular in Gaetice, Gopkittisak, and Sestrostoma. The exopod of the third maxilliped is fully exposed (Gaetice) or slightly hidden mesially (Gopkittisak and Sestrostoma). The first gonopod is triangular in cross-section in all three genera.

As Cuesta et al. (2005) noted, substantial similarity is seen between the first stage zoea of $P$. carinata, which was described by Muraoka (1985), and those of the other known varunid taxa. Shared characters include the possession of dorsolateral knobs on the second and third abdominal somites, the distally forked telson without armature, $2+2$ maxillar setation, and $0,1,5(6)$ setation of the endopod of the second maxilliped (cf. Hart 1935; Kurata 1968a, b; Wear 1970; Morita 1974; Scelzo and Lichtschein de Bastida 1979; Wilson 1980; Terada 1981; Kim and Lee 1983; Kim and Jang 1987; Lee 1988; Kim and Hwang 1990; Rodrígez et al. 1992; Hwang et al. 1993; Guerao et al. 1995; Hwang and Kim 1995; Cuesta and Schubart 1997; Cuesta et al. 2000, 2001; Spivak and Cuesta 2000). However, the antenna of the first zoea of $P$. carinata has a reduced exopod, and in this regard is unique among known varunids but similar to first zoeae of species of Plagusia in the Plagusiidae Dana, 1851 (see Schubart et al. 2010). This could be the result of convergence rather than an indication of a close relationship. In addition, the presence of three setae on the basal segment of the first maxilliped and the three-segmented endopod of the second maxilliped, which are typical of first zoeae of Grapsoidea but not Pinnotheroidea, further support the removal of Pseudopinnixa from the Pinnotheridae.

\section{Pseudopinnixa carinata Ortmann, 1894}

(Figs 1-5)

Pseudopinnixa carinata Ortmann, 1894: 694, pl. 23, fig. 6; Tesch 1918: 287 (list); Sakai 1939: 600; 1955: 110; 1976: 586 (English text), pl. 203, fig. 1; Schmitt et al. 1973: 126 (bibliography); Miyake 1983: 243 (list); Muraoka 1998: 

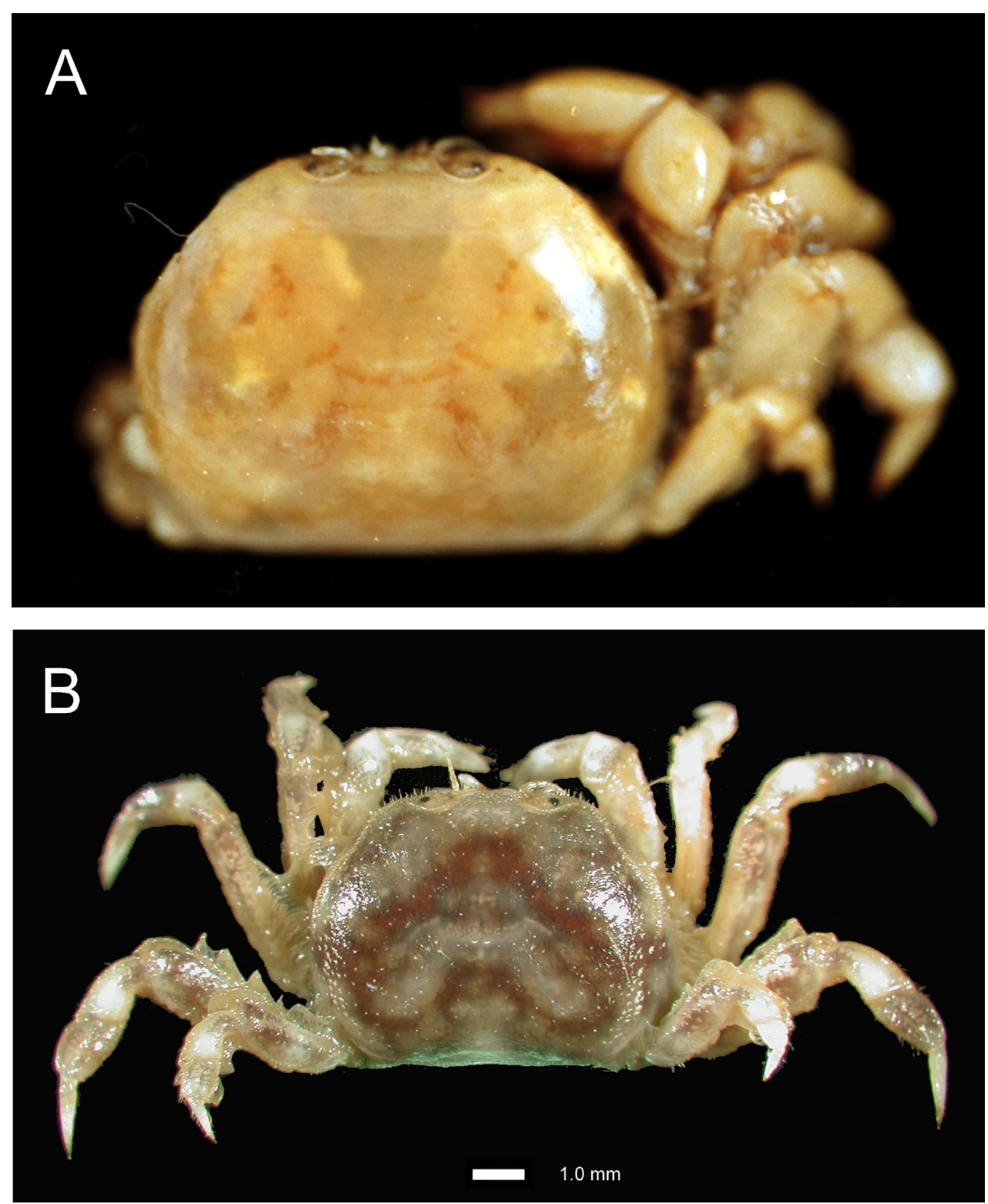

Fig. 1. Pseudopinnixa carinata Ortmann, 1894. A, Syntype, male $(12.5 \times 15.4 \mathrm{~mm})$, MZS 1167, entire animal in dorsal view, right pereopods removed; B, male $(5.0 \times 7.2 \mathrm{~mm})$, CBM-ZC 9867, entire animal in dorsal view.

49; Komai 1999: 90; Marumura and Kosaka 2003: 68; $\mathrm{Ng}$ et al. 2008: 248 (list), 252 (mention); Palacios-Theil et al. 2009: 461 .

Material examined. Syntypes: 9 males $(11.0 \times 13.6$ to $13.2 \times 17.0 \mathrm{~mm}), 17$ females $(9.7 \times 12.5$ to $12.3 \times 16.0 \mathrm{~mm})$, Tokyo Bay, 1880-1881, coll. L. Döderlein, MZS 1167 (spirit); 1 male $(10.0 \times 13.0 \mathrm{~mm})$, same data, MZS 308 (dry); 3 males $(11.0 \times 14.5$ to $11.5 \times 15.6 \mathrm{~mm}), 2$ females $(12.1 \times 16.6$, $13.3 \times 17.4 \mathrm{~mm}$ ), same data, MZS 309 (dry).

Non-type: 1 male $(3.6 \times 4.8 \mathrm{~mm})$, RV Tansei-maru, KT955 cruise, stn TB-10, SE of Cape Taito, Misaki, Boso Peninsula, 54-55 m, 21 April 1995, dredge, coll. T. Komai, CBM-ZC 9303; 1 male $(5.0 \times 7.2 \mathrm{~mm})$, Kiso-sansen River estuary, Ise Bay, Mie Prefecture, intertidal sand flat, 30 April 2002, coll. H. Sekiguchi, CBM-ZC 9867; 1 male $(5.1 \times 6.8 \mathrm{~mm}), 1$ young female $(4.6 \times 6.6 \mathrm{~mm}), 9$ juveniles $(2.6 \times 3.0$ to $2.9 \times 3.5 \mathrm{~mm})$,
Miho Bay, Tottori Prefecture, $35^{\circ} 28.710^{\prime} \mathrm{N}, 133^{\circ} 18.414^{\prime} \mathrm{E}$, $9.3 \mathrm{~m}$, sand bottom, 18 August 2003, SM grab, CBM-ZC $8144 ; 2$ males $(4.6 \times 6.0 \mathrm{~mm}$, larger one badly damaged), 3 young females $(3.8 \times 5.2$ to $5.5 \times 7.3 \mathrm{~mm})$, similar locality, $35^{\circ} 28.903^{\prime} \mathrm{N}, 133^{\circ} 18.576^{\prime} \mathrm{E}, 12 \mathrm{~m}, 18$ August 2003 , SM grab, CBM-ZC $8145 ; 2$ males $(3.7 \times 5.0,7.9 \times 10.6 \mathrm{~mm}), 2$ young females $(4.3 \times 5.7,5.4 \times 7.3 \mathrm{~mm}), 4$ juveniles $(2.2 \times 2.7$ to $2.6 \times 3.0 \mathrm{~mm}$ ), similar locality, $35^{\circ} 29.089^{\prime} \mathrm{N}, 133^{\circ} 18.591^{\prime} \mathrm{E}$, $12.7 \mathrm{~m}$, sand, 30 January 2004, SM grab, CBM-ZC 8154; 1 female $(4.5 \times 6.4 \mathrm{~mm})$, similar locality, $5 \mathrm{~m}$, 30 January 2004, SM grab, CBM-ZC 10199.

Redescription. Adult male. Carapace (Figs 1A, B, 2A) 1.3-1.4 times wider than long, greatest width somewhat posterior to midlength; dorsal surface slightly convex transversely, somewhat more convex longitudinally, granulate adjacent to lateral margins, remaining part nearly smooth, with distinct submarginal ridge along posterior margin (Fig. 

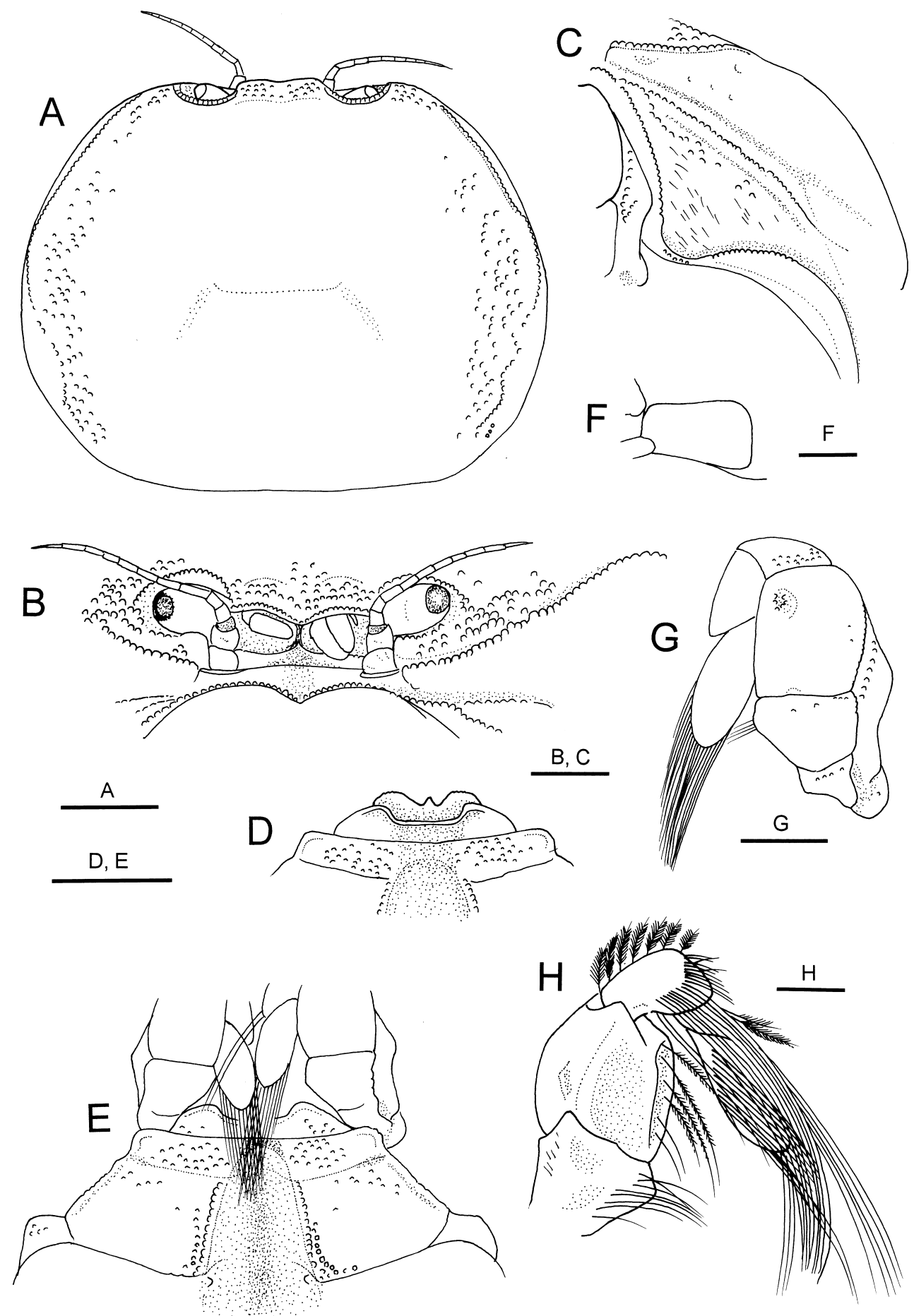

Fig. 2. Pseudopinnixa carinata Ortmann, 1894. A-G, Male (7.9×10.6 mm), CBM-ZC 8154; H, male (5.0×7.2 mm), CBM-ZC 9867. A, Carapace, dorsal view (setae omitted); B, frontal part of carapace and cephalic appendages, anterior view (setae omitted); C, left pterygostomial part of carapace, ventral view; D, first to third thoracic sternites, ventral view; E, second to anterior part of fifth thoracic sternites and basal parts of third maxillipeds, ventral view; F, left eighth thoracic sternite, posterior view; $G$, left third maxilliped, outer view; $H$, same, inner view (exopod removed). Scale bars: $2 \mathrm{~mm}$ for A, D, E; $1 \mathrm{~mm}$ for B, C, F, G; $0.5 \mathrm{~mm}$ for $\mathrm{H}$.

5A); regions not demarcated. Inter-orbital (Fig. 2B) area granulate; frontal margin granulate, slightly deflexed, slightly concave on either side of slightly produced, blunt midpoint; lateral frontal angle not produced. Anterolateral margin broadly arcuate, delimited by granulate ridge running from suborbital margin to branchial region; posterolateral margin not confluent with anterolateral margin. Epimera partially visible in dorsal view. Upper orbital margin granulate; lower orbital margin clearly separated from suborbital ridge, inner angle blunt, unarmed. Pterygostomial region (Fig. 2C) with slightly arcuate, granulate suborbital ridge extending from anterolateral angle of buccal frame; lower part with scattered short setae. Lateral margin of buccal frame with sharp, granulate carina. Epistome (Fig. 2B) relatively 

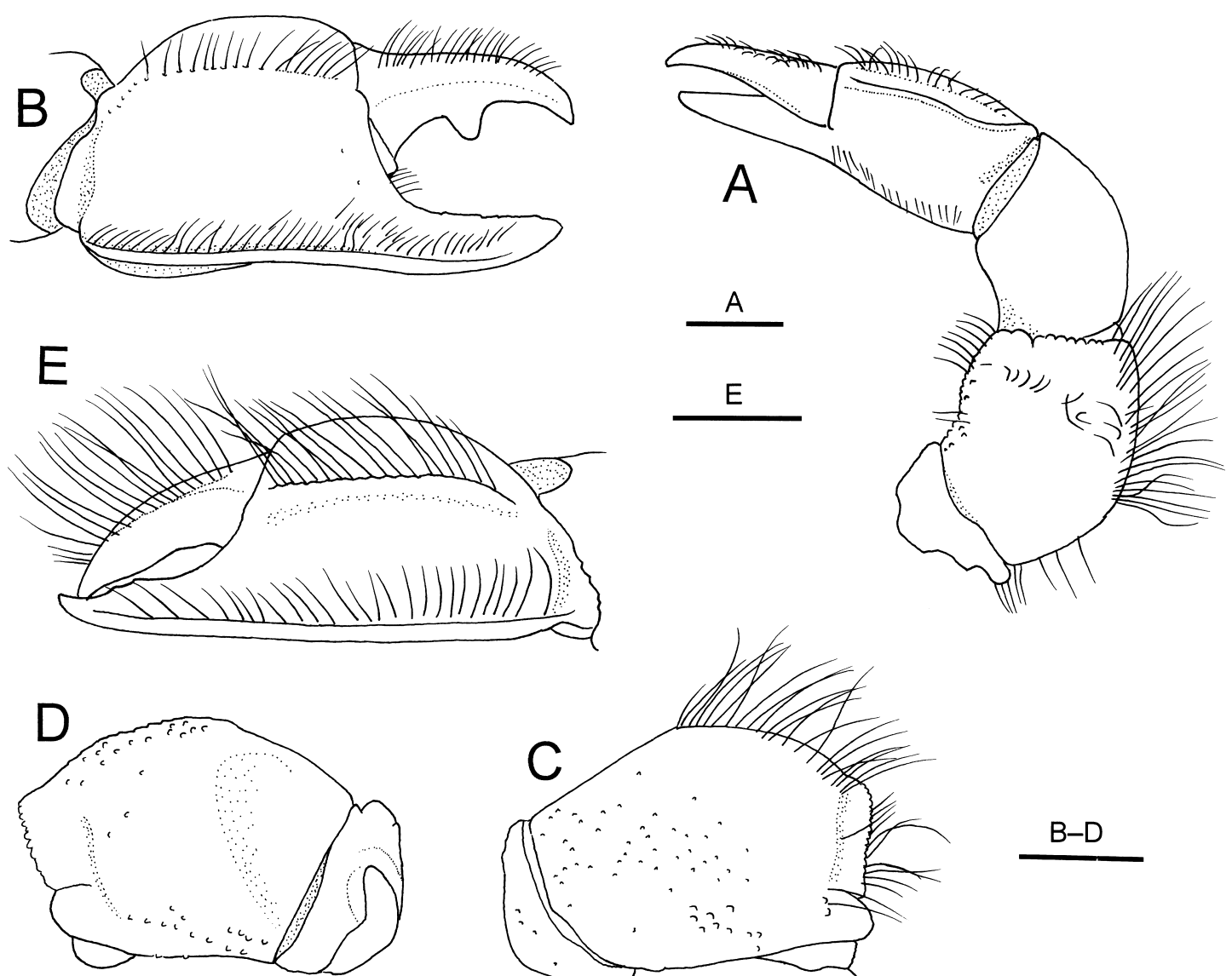

Fig. 3. Pseudopinnixa carinata Ortmann, 1894. A-D, Male $(7.9 \times 10.6 \mathrm{~mm})$, CBM-ZC 8154; E, female $(4.5 \times 6.4 \mathrm{~mm})$, CBM-ZC 10199. A, Entire right cheliped, dorsal view; B, same, chela, outer view; C, same, merus, outer view; D, same, inner view (setae omitted); B, chela of left cheliped, outer view. Scale bars: $1 \mathrm{~mm}$ for A-D; $0.5 \mathrm{~mm}$ for E.

short, ventral margin slightly produced into blunt point medially, shallowly concave on either side of midpoint; surface shallowly concave.

Eye (Fig. 2B) small, completely filling orbit, movable. Antennular basal segments separate by narrow median septum; antennular peduncle folding transversely (Fig. 2B). Antennal peduncle (Fig. 2B) vertical, reaching lateral frontal angle by distal margin of third segment; flagellum longer than width of front, consisting of 7-9 articles.

Third maxilliped (Fig. 2G, H) with numerous elongate setae on inner surface of carpus and inner surface and margins of dactylus. Merus with shallow depression filled with small granules distomesially on outer face; inner face shallowly depressed in medial half, with distinct longitudinal groove along mesial margin, distal margin produced into triangular lobe. Carpus sparsely granulate on outer surface. Articulation between propodus and dactylus strongly oblique. Propodus with few moderately long setae on inner face. Dactylus elongate oval, spatulate. Exopod covered by lateral margin of ischium-merus in mesial half, having strongly sinuous lateral margin; outer face with longitudinal row of granules delimiting shallowly depressed mesial half.

Chelipeds equal or subequal, similar (Figs 1B, 3A). Chela (Fig. 2A, B) relatively small, length $0.30-0.55$ of carapace width; fingers crossing at tip when closed. Dactylus subequal in length to palm, slightly curving, terminating in subacutely pointed tip; outer face with row of short, stiff setae adjacent to dorsal margin; dorsal surface rounded; cutting edge with a median tooth (in largest specimen, tooth prominent). Fixed finger nearly straight, unarmed along cutting edge. Palm approximately as long as high; dorsal margin keeled, gently arcuate in outer view; outer face with longitudinal row of setae dorsally, sharply carinate ventrally including fixed finger, bearing row of setae; inner face with sparse setae; ventral margin sinuous in outer view. Carpus subequal in length to palm measured along dorsal margin, lacking prominent spine or tooth, surfaces nearly smooth; inner face with granules dorsally and ventrally. Merus (Fig. 2C, D) stout; dorsal margin convex, with row of long setae on distal half; outer (posterior) face sparsely granulate, outer ventral margin nearly straight; inner face with granules dorsally and ventrally, otherwise nearly smooth; distal margin granulate. Ischium very short.

Eye (Fig. 2B) small, completely filling orbit, movable. Antennular basal segments separate by narrow median septum; antennular peduncle folding transversely (Fig. 2B). Antennal peduncle (Fig. 2B) vertical, reaching lateral frontal angle by distal margin of third segment; flagellum longer than width of front, consisting of 7-9 articles.

Ambulatory legs (Figs 1B, 4A-E) moderately short and stout. Third and fourth pereopods (second and third ambulatory legs) subequal in length, longer than second and 


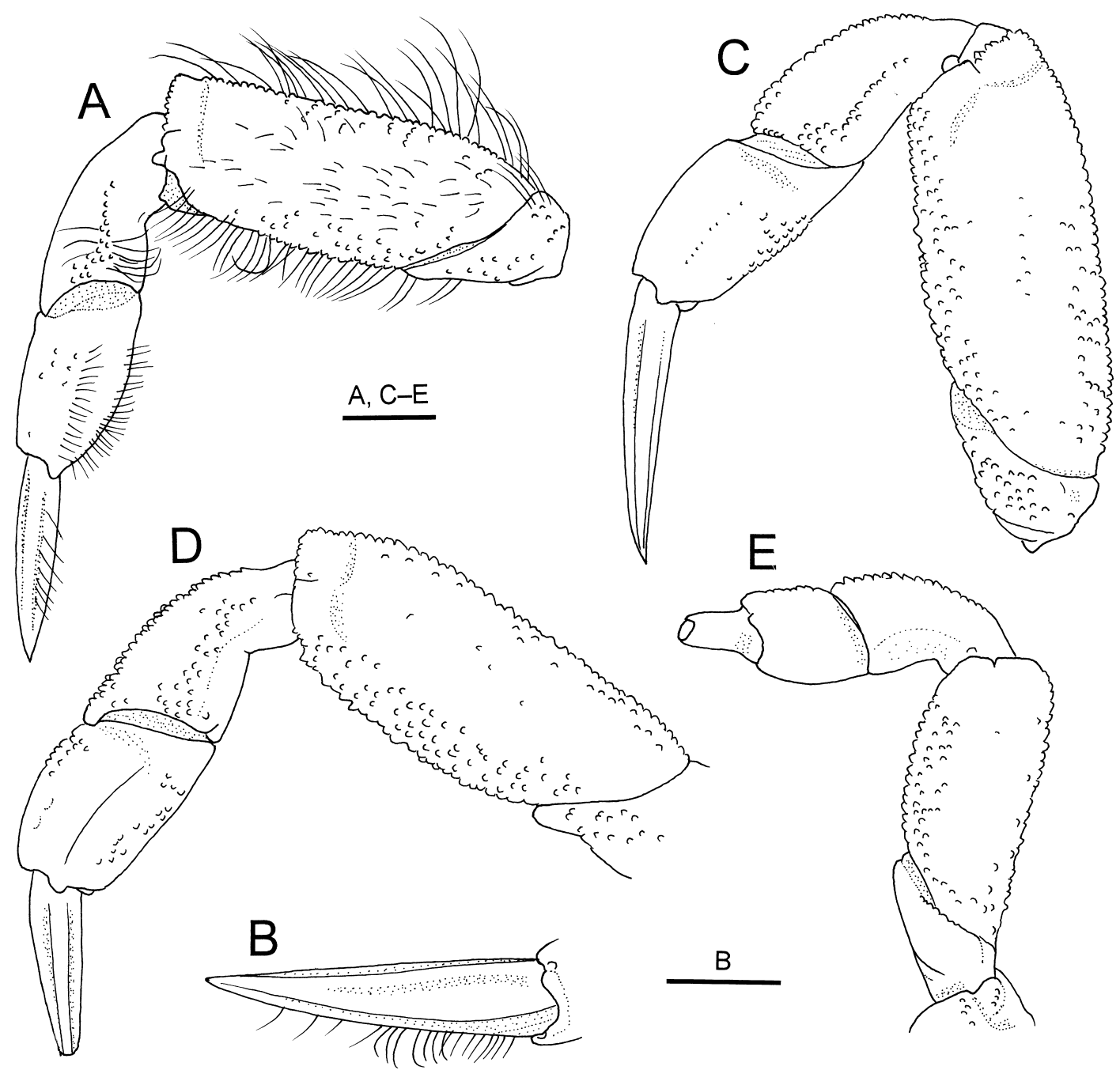

Fig. 4. Pseudopinnixa carinata Ortmann, 1894 , male $(7.9 \times 10.6 \mathrm{~mm})$, CBM-ZC 8154 . A, Left second pereopod (first ambulatory leg), posterior view; B, same, dactylus, extensor view; C, left third pereopod (second ambulatory leg), posterior view (setae omitted); D, left fourth pereopod (third ambulatory leg), posterior view (setae omitted, distal part of dactylus broken off); E, left fifth pereopod (fourth ambulatory leg), posterior view (setae omitted, distal part of dactylus broken off). Scale bars: $1 \mathrm{~mm}$.

fifth pereopods (first and fourth ambulatory legs), lengths 1.1-1.2 times carapace width; fifth pereopod with merus reaching midlength of merus of fourth pereopod. Ischia with outer face granulate (second to fourth pereopods) or smooth (fifth pereopod). Meri coarsely granulate on upper and lower margins; posterior faces with scattered short setae and some short, transverse rows of granules on upper part and scattered coarse granules on lower part; row of setae on upper and lower margin. Carpi smooth (second pereopod) or coarsely granulate (third to fifth pereopods) on extensor margin; posterior faces with irregular longitudinal rows of granules along midline; propodi subequal in length to (second to fourth pereopods) or shorter than (fifth pereopod) carpi, bearing granules (second to fourth) or nearly smooth (fifth). Dactyli longer than propodi measured along extensor margin, each gradually tapering to acute apex, somewhat flattened lance-shaped (on second to fourth) or subconical (on fifth); extensor surface with 2 (on second and third) or 4 shallow longitudinal sulci, median part somewhat elevated; posterior and anterior margins bluntly carinate in second to fourth pereopods; flexor surface with 2 shallow longitudinal sulci flanking slightly elevated median part.

First to third thoracic sternites (Fig. 2D, E) clearly divided by distinct sutures. First and second sternites deeply depressed; first sternite trilobed anteriorly with median tubercle and noticeably produced anterolateral angles. Second sternite having distinct carina bordering anterior margin, anterolateral angles produced anteriorly. Third and fourth sternites granulate, medially slightly concave. Fifth sternite with small, tubercular abdomen locking press button at anteromesial portion. Exposed part of eighth sternite subquadrate, nearly smooth on surface. Penis sternal, located at anterior end of eighth sternite. Sterno-abdominal cavity bordered by granulate ridge, more distinct on fourth sternite.

Gill formula summarized in Table 1; second maxilliped with small podobranchia; third maxilliped with small podobranchia and 2 greatly unequal, well developed arthrobranchiae (second gill much larger than first gill); first pereopod 

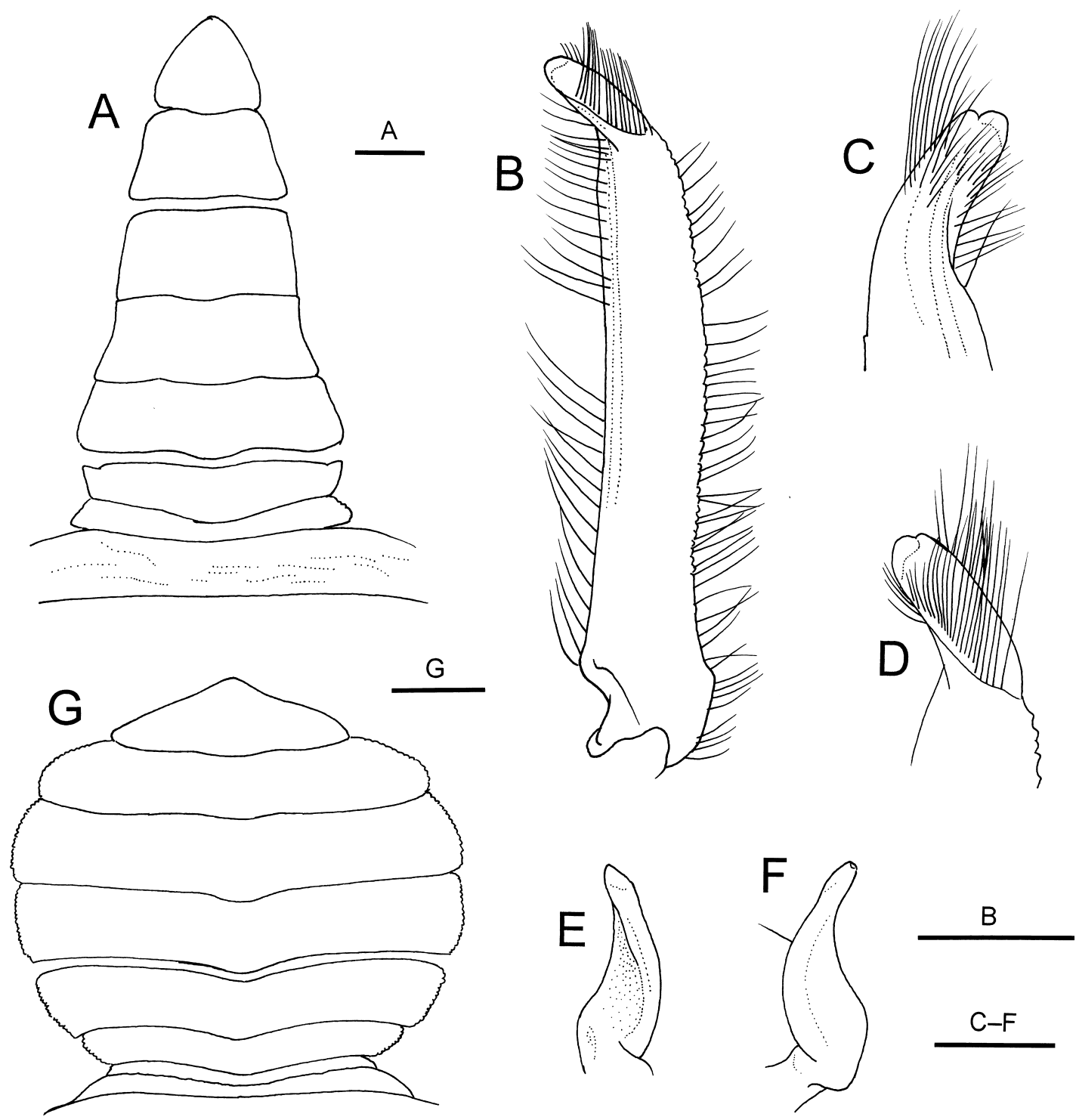

Fig. 5. Pseudopinnixa carinata Ortmann, 1894. A-F, Male $(7.9 \times 10.6 \mathrm{~mm})$, CBM-ZC 8154; G, female $(4.5 \times 6.4 \mathrm{~mm})$, CBM-ZC 10199. A, G, Abdomen, outer view; B, left first gonopod, mesial view; C, same, distal part, lateral view; D, same, mesial view; E, second gonopod, mesial view; F, same, lateral view. Scale bars: $1 \mathrm{~mm}$ for A, B, G; $0.5 \mathrm{~mm}$ for C-F.

Table 1. Gill formula of Pseudopinnixa carinata Ortmann, 1894.

\begin{tabular}{lcccccccc}
\hline \multirow{2}{*}{$\begin{array}{c}\text { Gills/ } \\
\text { Appendages }\end{array}$} & \multicolumn{3}{c}{ Maxillipeds } & \multicolumn{5}{c}{ Pereopods } \\
\cline { 2 - 9 } & I & II & III & I & II & III & IV & V \\
\hline Pleurobranch & - & - & - & - & 1 & - & - & - \\
Arthrobranch & - & - & 2 & 2 & - & - & - & - \\
Podobranch & - & 1 & 1 & - & - & - & - & - \\
Epipod & 1 & 1 & 1 & - & - & - & - & - \\
\hline
\end{tabular}

with 2 large arthrobranchiae; pleurobranchia above base of second pereopod smaller than arthrobranchiae on first pereopod.

Abdomen (Fig. 5A) moderately narrow, with third to sixth somites functionally fused, although sutures dividing somites distinct. First and second somites short, smooth on outer faces. Third somite widest, with rounded proximolateral angles. Fourth somite with concave lateral margins. Tel- son subtriangular with blunt tip, nearly as long as wide.

First gonopod (Fig. 5B-D) moderately slender, laterally compressed with cross section subovate, reaching suture between third and fourth thoracic sternite, distally curving dorsally; ventral margin bordered by granules over entire length; chitinous terminal process somewhat flattened, shallowly concave on mesial side, distally rounded, obscured by numerous stiff setae. Second gonopod (Fig. 5E, F) small, 
moderately stout, sinuous, tapering distally.

Female. Generally similar to adult males, but chela (Fig. $3 \mathrm{E})$ proportionally smaller, ventral margin almost straight, setae longer than in males, lacking tooth on cutting edge of dactylus. Abdomen (Fig. 5G) broad, subcircular, broadest at fourth and fifth somites; first somite with distinct transverse ridge running across entire width; lateral margins of second to sixth somites minutely granulated, those of sixth somite strongly convex proximally; telson broadly subtriangular, 3.0 times broader than long, distolateral margins faintly concave.

Coloration in life. Body and appendages generally gray; carapace with brown markings surrounding median part.

Distribution. Known only from Japan: off Cape Inubo and off Misaki, Chiba Prefecture; Tokyo Bay; Osaka Bay; Miho Bay, Tottori Prefecture; Moji, Fukuoka Prefecture; intertidal to $55 \mathrm{~m}$ (Ortmann 1894; Sakai 1976; Marumura and Kosaka 2003; Palacios-Theil et al. 2009; this study).

Habitat. Occurring on muddy sand bottoms and probably burrowing in sediments. There is no evidence of association with other inverterbates.

Remarks. Ortmann (1894) listed 13 males and 19 females examined in his account of Pseudopinnixa carinata, although he did not designate a holotype. Therefore, these 32 specimens are syntypes. During a stay in the Musée Zoologique, Strasbourg, in 1997 and 1998, the first author located all these specimens, although they were separated into three differently preserved lots. Nine males and 17 females (MZS 1167) were preserved in ethanol and are in good condition. Three males and two females (MZS 309) are now dried. One male specimen in dry condition was found in the box containing the syntypes of Pinnaxodes major Ortmann, 1894 (MZS 308), but it was probably just misplaced. There is no doubt that these syntypic specimens all represent the same species. As the genus is monotypic and there are no known taxonomic or nomenclatural problems associated with this species, we do not see the need to select a lectotype for the time being.

The six subadult specimens $(3.8 \times 5.2$ to $5.5 \times 7.3 \mathrm{~mm}$; CBM-ZC 8144, 8145, 8154) are androgynous in having a triangular abdomen with functionally fused third to sixth somites, which is proportionally slightly wider than in normal males, gonopores on the sixth thoracic sternite, and biramous first to fourth pleopods. The smallest normal female is $4.5 \times 6.4 \mathrm{~mm}$ (CBM-ZC 10199), i.e., within the size range of these aberrant specimens. Androgyny in the Brachyura is little known, although Ahyong and Ng (2008) demonstrated examples of this sexual aberration in four species in two genera of Pinnotheridae.

\section{Acknowledgments}

We sincerely thank Hideo Sekiguchi (Professor Emeritus, Mie University) for providing the specimen from Ise Bay, and Peter K. L. Ng (National University of Singapore) and three anonymous referees for reviewing the manuscript.
Editorial comments from Mark J. Grygier (Lake Biwa Museum) are much appreciated. This study was supported partially by a Grant-in-Aid for International Scientific Research (Number 09041155) from the Japanese Ministry of Education, Science and Culture (Dr. Teruaki Nishikawa, principal investigator).

\section{References}

Ahyong, S. T. and Ng, P. K. L. 2008. Alain raymondi, a new species of deepwater pinnotherid crab (Crustacea: Decapoda: Brachyura) from the Philippines, commensal with holothurians. Zootaxa 1919: 61-68.

Ahyong, S. T. and Ng, P. K. L. 2009. Aphanodactylidae, a new family of thoracotreme crabs (Crustacea: Brachyura) symbiotic with polychaete worms. Zootaxa 2289: 33-47.

Cuesta, J. A., Diesel, R. and Schubart, C. D. 2001. Re-examination of the zoeal morphology of Chasmagnathus granulatus, Cyclograpsus lavauxi, Hemigrapsus sexdentatus, and $H$. crenulatus confirms consistent chaetotaxy in the Varunidae (Decapoda, Brachyura). Crustaceana 74: 895-912.

Cuesta, J. A. and Schubart, C. D. 1997. The first zoeal stage of Glyptograpsus impressus, with comments on the subfamilial arrangement of Grapsidae (Crustacea: Brachyura). Cahiers de Biologie Marine 38: 291-299.

Cuesta, J. A., Schubart, C. D. and Felder, D. L. 2005. Systematic position of the Asthenognathinae Stimpson, 1858 and Pseudopinnixa carinata Ortmann (Decapoda, Brachyura): New Findings from Larval and DNA Comparisons. Abstracts of the Sixth International Crustacean Congress, Glasgow, p. 127.

Cuesta, J. A., Schubart, C. D. and Rodrígez, A. 2000. Larval development of Brachynotus sexdentatus (Risso, 1827) (Decapoda, Brachyura) reared under laboratory conditions, with notes on larval characters of the Varunidae. Invertebrate Reproduction \& Development 383: 207-223.

Davie, P. K. L. and Ng, N. K. 2007. Two new subfamilies of Varunidae (Crustacea: Brachyura), with descriptions of two new genera. The Raffles Bulletin of Zoology (Supplement 16): 257-272.

Guerao, G., Cuesta, J. A., Abelló, P. and González-Gordillo, J. I. 1995. Larval development of Brachynotus gemmellari (Rizza, 1839) (Brachyura, Grapsidae) reared under laboratory conditions. Journal of Plankton Research 17: 1143-1161.

Hart, J. F. L. 1935. The larval development of British Columbia Brachyura. I. Xanthidae, Pinnotheridae (in part) and Grapsidae. Canadian Journal of Research 12: 411-432.

Holmes, S. J. 1894. Notes on West American Crustacea. Proceedings of the California Academy of Science (2) 4: 563-587, pls 20, 21.

Hwang, S. G. and Kim, C. H. 1995. Zoeal stages and megalopa of $\mathrm{He}$ migrapsus penicillatus (De Haan, 1835) (Decapoda, Brachyura, Grapsidae) reared in the laboratory. Korean Journal of Systematic Zoology 11: 389-408.

Hwang, S. G., Lee, C. and Kim, C. H. 1993. Complete larval development of Hemigrapsus sanguineus (Decapoda, Brachyura, Grapsidae) reared in the laboratory. Korean Journal of Systematic Zoology 9: 69-86.

Kim, C. H. and Hwang, S. G. 1990. The complete larval development of the mitten crab Eriocheir japonicus de Haan (Crustacea, Brachyura, Grapsidae) reared in the laboratory. Korean Journal of Zoology 33: 411-427.

Kim, C. H. and Jang, K. I. 1987. The complete larval development of the mitten crab Acmaeopleura parvula Stimpson (Brachyura, Grapsidae) reared in the laboratory. Bulletin of the Korean Fishery Soci- 
ety 20: $543-560$.

Kim, C. H. and Lee, H. J. 1983. Zoeal development of Gaetice depressus (De Haan) (Decapoda, Grapsidae) reared in the laboratory. Journal of Science of the Pusan National University, Korea 35: 195-206.

Komai, T. 1999. Decapod Crustacea collected by L. Döderlein in Japan and reported by Ortmann (1890-1894) in the collection of the Musée Zoologique, Strasbourg. Pp. 53-101. In: Nishikawa, T. (Ed.) Preliminary Taxonomic and Historical Studies on Prof. Ludwig Döderlein's Collection of Japanese Animals Made in 1880-81 and Deposited at Several European Museums. Report of Activities in 1997-98 supported by Grant-in-Aid for International Scientific Research (Field Research), No. 09041155.

Kurata, H. 1968a. Larvae of Decapoda Brachyura of Arasaki, Sagami Bay. I. Acmaeopleura parvula Stimpson (Grapsidae). Bulletin of Tokai Regional Fisheries Research Laboratory 55: 259-263.

Kurata, H. 1968b. Larvae of Decapoda Brachyura of Arasaki, Sagami Bay. II. Hemigrapsus sanguineus (De Haan) (Grapsidae). Bulletin of Tokai Regional Fisheries Research Laboratory 56: 167-171.

Lee, H. J. 1988. The larval development of four species of grapsid crabs (Decapoda, Grapsidae) reared in the laboratory. Ph.D. Dissertation. Pusan National University, Korea, 78 pp.

MacLeay, W. S. 1838. On the brachyurous decapod Crustacea brought from the Cape by Dr. Smith. Pp. 53-71. In: Smith, A. (Ed.) Illustrations of the Annulosa of South Africa; being a Portion of the Objects of Natural History Chiefly Collected during an Expedition into the Interior of South Africa, under the Direction of Dr. Andrew Smith, in the Years 1834, 1835, and 1836; Fitted Out by "The Cape of Good Hope Association for Exploring Central Africa." Smith, Elder, and Co., London.

Marumura, M. and Kosaka, A. 2003. Catalogue of Brachyuran and Anomuran Crabs Collection Donated by the Late Mr. Seiji Nagai to the Wakayama Prefectural Museum of Natural History. Wakayama Prefectural Museum, Kainan, 74 pp., 8 pls. [In Japanese]

Milne Edwards, H. 1853. Mémoires sur la famillie des Ocypodiens, suite. Annales des Sciences Naturelles (3) 20: 163-228, pls 6-11.

Miyake, S. 1983. Japanese Crustacean Decapods and Stomatopods in Color. Vol. II. Brachyura (Crabs). Hoikusha, Osaka, 277 pp., 64 pls.

Morita, T. 1974. Morphological observation on the development of larva of Eriocheir japonica De Haan. Zoological Magazine, Tokyo 83: 24-81.

Muraoka, K. 1985. The first zoea of Pseudopinnixa carinata Ortmann (Crustacea, Brachyura, Pinnotheridae). Bulletin of the Kanagawa Prefectural Museum 16: 1-5.

Muraoka, K. 1998. Catalogue of the brachyuran and anomuran crabs donated by Prof. Dr. Tune Sakai to the Kanagawa Prefectural Museum. Catalogue of the Collection in the Kanagawa Prefectural Museum of Natural History 11: 1-67, pls 1-16.

Naruse, T. and Clark, P. F. 2009. Establishment of a new genus for Asthenognathus gallardoi Serène \& Soh, 1976 within Gaeticinae Davie \& Ng, 2007 (Crustacea: Decapoda: Brachyura: Varunidae). Zootaxa 1987: 61-68.

Ng, P. K. L., Guinot, D. and Davie, P. J. F. 2008. Systema Brachyurorum: Part 1. An annotated check list of extant brachyuran crabs of the world. The Raffles Bulletin of Zoology (Supplement 17): 1-286.

Ortmann, A. E. 1894. Die Decapoden-Krebse des Strassburger Muse- um, mit besonderer Berücksichtigung der von Herrn Dr. Döderlein bei Japan und bei den Liu-Kiu-Inseln gesammelten und zur Zeit in Strassburger Museum aufbewahrten Formen. VIII. Theil. Abtheilung: Brachyura (Brachyura genuina Boas) III. Unterabtheilung: Cancroidea, 2. Section: Cancridea, 2. Gruppe: Catametopa. Zoologische Jahrbücher, Abtheilung für Systematik, Geographie und Biologie der Thiere 7: 683-772, pl. 23.

Palacios-Theil, E., Cuesta, J. A., Campos, E. and Felder, D. L. 2009. Molecular genetic re-examination of subfamilies and polyphyly in the family Pinnotheridae (Crustacea: Decapoda). Pp. 457-474. In: Martin, J. W., Crandall, K. A. and Felder, D. L. (Eds) Decapod Crustacean Phylogenetics. Crustacean Issues 18. CRC Press, Taylor \& Francis Group, Boca Raton, London, New York.

Rodrígez, A., González-Gordillo, J. I. and Cuesta, J. A. 1992. Larval stages of Brachynotus atlanticus Forest, 1957 (Crustacea, Decapoda, Grapsidae) reared under laboratory conditions. Journal of Plankton Research 14: 867-883.

Sakai, T. 1939. Studies on the Crabs of Japan. IV. Brachygnatha, Brachyrhyncha. Yokendo, Tokyo, pp. 365-741, pls 42-111.

Sakai, T. 1955. On some rare species of crabs from Japan. Bulletin of the Biogeographical Society of Japan 16-19: 106-113.

Sakai, T. 1965. The Crabs of the Sagami Bay, Collected by His Majesty the Emperor of Japan. Edited by the Biological Laboratory, Imperial Household, Tokyo, 206 pp., pls 1-100. Maruzen, Tokyo.

Sakai, T. 1976. Crabs of Japan and the Adjacent Seas. Kodansha, Tokyo, xxix +773 pp. (English text), $461 \mathrm{pp.} \mathrm{(Japanese} \mathrm{text),}$ 16 pp. +251 pls.

Scelzo, M. A. and Lichtschein de Bastida, V. 1979. Desarrollo larval y metamorfosis del cangrejo Cyrtograpsus altimanus Rathbun, 1914 (Brachyura, Grapsidae) en laboratorio, con observaciones sobre la ecología de especie. Physis, Seccion A 38: 103-126.

Schmitt, W. L., McCain, J. C. and Davidson, E. 1973. Decapoda I. Brachyura I. Fam. Pinnotheridae. Crustaceorum Catalogus 3: $1-160$.

Schubart, C. D. and Cuesta, J. 2010. Phylogenetic relationships of the Plagusiidae Dana, 1851 (Brachyura), with description of a new genus and recognition of Percnidae Stevcic, 2005, as an independent family. Pp. 279-299. In: Castro, P., Davie, P. J. F., Ng, P. K. L. and Richer de Forges, B. (Eds) Studies on Brachyura: An Homage to Daniéle Guinot. Crustaceana Monographs, Vol. 11. Brill, Leiden.

Spivak, E. and Cuesta, J. A. 2000. Larval development of Cyrtograpsus affinis (Dana) (Decapoda, Brachyura, Varunidae) from Río de la Plata estuary, reared in the laboratory. Scientia Marina 69: 29-47.

Terada, M. 1981. Zoea larvae of five crabs in the subfamily Varuninae. Researches on Crustacea 11: 66-76.

Tesch, J. J. 1918. The Decapoda Brachyura of the Siboga-Expedition. II. Goneplacidae and Pinnotheridae. Siboga-Expeditie 39c ${ }^{1}: 149-295$, 12 pls.

Wear, R. G. 1970. Life history studies on New Zealand Brachyura. 4. Zoea larvae hatched from crabs of the family Grapsidae. New Zealand Journal of Marine and Freshwater Research 4: 3-35.

Wilson, K. A. 1980. Studies on decapod Crustacea from the Indian River region of Florida. XV. The larval development under laboratory conditions of Euchirograpsus americanus A. Milne Edwards, 1880 (Crustacea Decapoda: Grapsidae) with notes on grapsid subfamilial larval characters. Bulletin of Marine Science 30: 756-775. 